\title{
The Procedural Justice Model as Reform
}

Accounts of the shooting differ. Ferguson police officer Darren Wilson testified that he first encountered Michael Brown and Dorian Johnson as they walked down the middle of Canfield Drive on August 9, 2014. ${ }^{1}$ Wilson had just finished a call for a sick baby at a nearby apartment, during which he heard a call go out about a theft in progress at a market on West Florissant Street. Wilson was not dispatched to the theft scene, and he had heard only parts of the communication over his portable radio, but he reportedly knew that the suspect was wearing a black shirt and that a box of cigarillos had been taken. As Johnson, 22, and Brown, 18, walked one behind the other near the double yellow line, traffic flow was paused as cars took turns going around them. Officer Wilson, a large man at nearly $6^{\prime} 4$ " and 210 pounds, stopped as the young men approached his Tahoe, and when Johnson passed his side-view mirror, Wilson said, "Why don't you guys walk on the sidewalk?" Johnson replied, "We are almost to our destination" and continued walking, and as Brown approached the car's mirror Wilson said, "Well, what's wrong with the sidewalk?" Brown retorted, "Fuck what you have to say," attracting extra attention from Wilson, who then noticed that Brown carried a box of cigarillos in his right hand, and also that he wore a black shirt, matching the description of the suspect in the theft at the market.

Wilson notified the dispatcher that he was "on Canfield with two" and asked for another car, and then he backed the Tahoe up past Johnson and Brown, angling the car across the middle of the road. He started to open the car door and said to Brown, "Hey, come here for a minute," but Brown, 6' 4" and 292 pounds, shut the door saying, "What the fuck are you going to do about it." Wilson tried to move Brown back with the door and said, "Get the fuck back," but Brown 
pushed back, shutting the door, and struck Wilson in the face with his hand. Brown turned to Johnson and handed him the cigarillos, now in Brown's left hand, and said, "Hey, man, hold these," and Wilson grabbed Brown's right arm. As he later explained to the grand jury, he "felt like a five year old holding on to Hulk Hogan" (the professional wrestler). Brown struck Wilson again, and as they struggled, Wilson considered his options: his mace, which he could not readily reach, and which posed the risk of incapacitating Wilson more than Brown; his expandable baton, on which he was partially sitting, making it awkward to draw; his flashlight, on the passenger side of the car, which he considered to be of dubious effectiveness in close quarters; and his firearm. He drew his gun and told Brown, "Get back or I am going to shoot you." Brown grabbed the gun, pushing it into Wilson's hip, and said, "You are too much of a pussy to shoot me." As Wilson pulled the gun up, with Brown still holding onto it as well, he pulled the trigger; after two clicks, the gun discharged on the third pull, the bullet going through the door panel, breaking the retracted window and causing glass to fly out. Both parties were startled.

Brown stepped back at that point, and according to Wilson, "He looked up at me and had the most intense aggressive face. The only way I can describe it, it looks like a demon, that's how angry he looked." Brown came back toward Wilson then, and Wilson tried to fire again, but the gun did not discharge. Wilson racked the slide and pulled the trigger again, and the gun fired, the bullet grazing Brown's hand. Brown turned and ran west on Canfield, and Wilson got out, notifying dispatch that shots had been fired. Wilson gave chase until Brown stopped and turned toward him, whereupon Wilson told him to get on the ground. When Brown started running at Wilson, Wilson started firing. Wilson saw Brown's body jerk and inferred that Brown had been struck at least once, but Brown continued to approach, and so Wilson started backpedaling and resumed firing. He saw Brown flinch but not stop, and "at that point it looked like he was almost bulking up to run through the shots, like it was making him mad that I'm shooting at him." When Brown was eight to ten feet away, he leaned forward as if he intended to tackle Wilson, and Wilson fired again. Brown went down, face first.

According to Brown's companion that day, Dorian Johnson, Wilson's first words to him and Brown were "Get the fuck on the sidewalk," and Johnson insisted that Brown said nothing to Wilson until after Wilson backed his car up to intersect them. ${ }^{2}$ Once Wilson backed up, though, he asked them, "What did you say?" Wilson opened his car door and, because they were so close to the car, the door hit both Johnson and Brown, and the door "closed back on him [Wilson], like real fast." Wilson then grabbed Brown's shirt around the neck area. Brown put his hands on the car and tried to pull away. Johnson heard Brown and Wilson talking to one another, "yelling and cussing," and saw them engaged in a "tug of war." Brown was pulling away as Wilson tried to pull him into the car, Wilson's left hand 
on Brown's right arm. Johnson never saw Brown's hand touch Wilson's gun, nor did he see Brown at any time form a fist or strike Wilson.

Other witnesses provided testimony to the St. Louis County grand jury, and their accounts varied. Some said that Brown was surrendering when Wilson fired the fatal shots; others said that Brown was shot in the back. Several witnesses saw the conflict between Brown and Wilson, and some said that they saw Brown punch Wilson while Brown was partly inside the Tahoe. No camera recording, other than that of the theft at the Ferguson Market, was available. But Brown's blood or other DNA was found inside the driver's door, on the upper left thigh of Wilson's pants, and on Wilson's shirt and firearm. Reaching its conclusion more than three months after the shooting, the grand jury declined to indict Wilson. Announcing the grand jury decision, the St. Louis County prosecutor Robert McClulloch explained that physical evidence and the most credible witness testimony indicated that as Brown charged at Wilson, the officer fired five shots, and then fired another five shots as Brown made a "full charge" at Wilson (Eckholm 2014). A federal investigation into Wilson's actions concluded that his use of deadly force was not a violation of Brown's civil rights.

Ferguson, Missouri, is a small city of 21,000, two-thirds of whom are black. As in many American cities, Ferguson's police, with only four blacks on a force of fifty-three, have historically had a tense relationship with its black community. Michael Brown was black; Wilson is white. The deadly shooting sparked protests in Ferguson the next day, which became violent. Brown's death galvanized the Black Lives Matter movement, which organized a freedom ride to Ferguson (Day 2015; also see Luibrand 2015). Demonstrations continued episodically for weeks and months thereafter in Ferguson and elsewhere, reinforced by a series of incidents in which unarmed black men-and one youth-died at the hands of police, including Tamir Rice, 12, who was shot and killed by Cleveland police as he drew a toy gun from his waistband, in November 2014; Walter Scott, who was shot and killed by police in North Charleston, SC, in April 2015; Freddie Gray, who died as a result of injuries to his spinal cord sustained while being transported by Baltimore police, also in April 2015; and Samuel DuBose, who was shot and killed by police during a traffic stop in Cincinnati in July 2015. Parts of these and other incidents involving deadly force were captured in digital video, either by police cameras or citizens' smart phones.

In late 2014, a presidential task force was charged with formulating recommendations for (re)building public trust in policing, and the short ninety-day turnaround reflected the urgency of its work (President's Task Force on 21st Century Policing 2015). As we write in the fall of 2016 , police reform remains a salient issue. The President's Task Force issued its report and recommendations, and it also produced a guide to implementation for police agencies. The Federal Bureau of Investigation is committed to devising a system for collecting data on police use of deadly force, 
which until now has been reported only as justifiable homicides on a voluntary (and hence unsystematic) basis by police agencies.

But police conduct, and especially police use of force, has been a recurring issue in the United States and other Western countries. It arises with some frequency at the local level and at times on a national scale. Twenty-three years before Michael Brown was killed, the beating of Rodney King by police in Los Angeles attracted national attention. King was a black man who, at the conclusion of a vehicle pursuit, was tased, struck by batons, and kicked by four LAPD officers, while nineteen other officers watched. Much of the incident was captured on video by a citizen and later viewed by people across the United States. Los Angeles Mayor Tom Bradley formed an independent commission to investigate the use of excessive force by Los Angeles police, and the commission's report summarized a broadly conceived inquiry into organizational dynamics that underlay police use of force. Commonly known as the Christopher Commission, after its chairman, Warren Christopher, the report noted that "police violence is not a local problem" (Independent Commission on the Los Angeles Police Department 1991, i), and the reception of the report reflected the national character of the issue. For its part, Congress mandated that the Justice Department collect national data on the use of force by police.

Twenty-three years before the King beating, another commission issued a report. The National Advisory Commission on Civil Disorders, also known as the Kerner Commission, was appointed by President Lyndon Johnson in 1967 to inquire into the whys and wherefores of riots that rocked American cities. The purview of the Kerner Commission included but was by no means limited to police practices. And it found that: "Disorder did not erupt as a result of a single "triggering" or "precipitating" incident. Instead, it was generated out of an increasingly disturbed social atmosphere, in which typically a series of tension-heightening incidents over a period of weeks or months became linked in the minds of many in the Negro community with a reservoir of underlying grievances. At some point in the mounting tension, a further incident-in itself often routine or trivial-became the breaking point and the tension spilled over into violence."

Police actions comprised the "prior incidents" in almost half of the cases, and the "final" incidents in twelve of twenty-four cases. The Commission's recommendations for the police were:

- Review police operations in the ghetto to ensure proper conduct by police officers, and eliminate abrasive practices;

- Provide more adequate police protection to ghetto residents to eliminate their high sense of insecurity, and the belief of many Negro citizens in the existence of a dual standard of law enforcement;

- Establish fair and effective mechanisms for the redress of grievances against the police, and other municipal employees; 
- Develop and adopt policy guidelines to assist officers in making critical decisions in areas where police conduct can create tension;

- Develop and use innovative programs to ensure widespread community support for law enforcement;

- Recruit more Negroes into the regular police force, and review promotion policies to ensure fair promotion for Negro officers;

- Establish a "Community Service Officer" program to attract ghetto youths between the ages of 17 and 21 to police work. These junior officers would perform duties in ghetto neighborhoods, but would not have full police authority. (U.S. National Advisory Commission on Civil Disorders 1968)

Contemporary prescriptions for reform bear a fairly strong resemblance to those of nearly fifty years ago. One new development in the reform agenda, however, is an emphasis on procedural justice and police legitimacy. Building trust and legitimacy was the first of the six "pillars" identified by the President's Task Force, around which its analysis and recommendations were organized. Its report stresses that "[b]uilding trust and nurturing legitimacy on both sides of the police-citizen divide is not only the first pillar of this task force's report but also the foundational principle underlying this inquiry into the nature of relations between law enforcement and the communities they serve." Its first recommendation was that "[l]aw enforcement culture should embrace a guardian mindset to build public trust and legitimacy. Toward that end, police and sheriffs' departments should adopt procedural justice as the guiding principle for internal and external policies and practices to guide their interactions with the citizens they serve" (11).

Even before the events that propelled police shootings into national headlines, however, steps had been taken by the Department of Justice to launch the National Initiative for Building Community Trust and Justice, which enlisted six pilot sites, in each of which three interventions are being implemented. One of the interventions is procedurally just policing. Making procedural justice a central plank in the reform agenda rests on a substantial volume of research into citizens' perceptions of and attitudes toward the police.

Can and will reform predicated on procedural justice as the main determinant of public trust succeed? As well grounded in logic and empirical evidence as it appears to be, we are doubtful. We believe that a procedural justice model of policing, which we describe below, is likely to be weakly implemented in police organizations, despite the best of executive intentions, and also that improvements in the procedural justice with which police act in their interactions with citizens are unlikely to yield corresponding improvements in citizens' subjective experiences with police. Moreover, we believe that the prescription for a procedural justice model rests on a misdiagnosis of the fundamental issues.

Some explanation is in order. 


\section{POLICE LEGITIMACY AND PROCEDURAL JUSTICE}

When people have contacts with the police, the fairness with which police are perceived to act affects citizens' trust and confidence in the police and their sense that the police deserve to be obeyed-that is, the procedural justice that citizens subjectively experience affects the "legitimacy" of the police. A large body of social psychological research demonstrates the strength and consistency of these empirical relationships. Procedural justice, this research tells us, is a matter of treating people with dignity and respect, giving them an opportunity to explain their situations and listening to what they have to say, and explaining what police have done and/or will do, so that it is clear that officers are taking account of people's needs and concerns and basing police decisions on facts. This research further tells us that legitimacy is important, not only for its own sake but because it has consequences. People who believe that police are legitimate are more likely to accept police decisions and comply with police requests and directives, more likely to cooperate with the police, and more likely even to abide by the law.

Legitimacy is, in the context of this social psychological research, an abstract outlook, with both cognitive and affective elements. It is subjective in nature, but as we discuss below, it is affected by citizens' experiences. As the National Research Council's Committee to Review Research has observed: "Legitimacy is the property that a rule or an authority has when others feel obligated to voluntarily defer to that rule or authority. In other words, a legitimate authority is one that is regarded by people as entitled to have its decisions and rules accepted and followed by others" (National Research Council 2004, 297).

The legitimacy of the police is thought to be important for several reasons. First, research suggests that citizens who see the police as legitimate are, in their interactions with the police, more likely to comply with police commands, directions, and requests. In the micro-context of police-citizen encounters, citizens' compliance makes the performance of police tasks easier (Mastrofski, Snipes, and Supina 1996; McCluskey 2003; McCluskey, Mastrofski, and Parks 1999), and can be expected to result in less use of force by police and fewer injuries to both police and citizens. Second, citizens who see the police as legitimate might be expected to more readily cooperate with police and other legal actors, for example, in reporting crime, and perhaps in providing information (Hart and Rennison 2003). Third, citizens who regard legal authorities as legitimate may be less likely to break the law. Research on this question is hardly conclusive, but findings suggest that offenders may be less prone to recidivate when their treatment by the legal system conforms to principles of procedural justice (Paternoster et al. 1997; also see Tyler 1990; Tyler and Huo 2002).

Legitimacy and other attitudes toward the police, extant research suggests, comprise a stock that police can either build or deplete through their performance, though it is also clear that the public's attitudes toward the police are to a 
significant extent shaped by forces beyond the control of police. ${ }^{3}$ Several elements of procedural justice shape citizens' subjective experience:

- People are more satisfied when they have an opportunity to "tell their side of the story"- to explain their situation or behavior to authorities.

- People are more satisfied when they believe that authorities' decisions are based on facts.

- People are more satisfied when they feel that they have been treated with dignity and respect.

- People are more satisfied when they trust authorities' motives, which is more likely when authorities explain their actions in terms that demonstrate that they have taken account of citizens' concerns and needs. ${ }^{4}$

Thus the research suggests that, in the words of the Committee to Review Research, legitimacy is "created" in individual encounters, and is also created in a more general form by the aggregated actions of police: "When a police officer responds to a call or stops someone on the street, what happens affects general feelings that people have regarding the extent to which authorities are legitimate and entitled to be obeyed" (National Research Council, 2004, 298). The effects of each contact on the attitude of the citizen participant are quite modest. The effects may be somewhat greater when we take account of both direct and indirect experiences, as the effects of vicarious experience ripple through circles of relatives, friends, and neighbors (Miller et al. 2003; Rosenbaum et al. 2005). The effects may be greater still as they accumulate across many contacts: in a single year, even in a fairly small city, police handle tens of thousands of calls for service, make thousands of arrests, issue thousands of traffic and other tickets, and have innumerable other contacts with the public. It may be possible to establish a reputation for treating people properly by earning it, through behavior that accords with principles of procedural justice. Given the asymmetrical effects of positive and negative experiences, which we discuss in a later chapter, it is easier to establish a reputation for treating people improperly by treating them unjustly, thereby eroding the stock of legitimacy. But the evidence base on which these expectations rest does not withstand close scrutiny, as we explain in later chapters.

\section{A PROCEDURAL JUSTICE MODEL OF POLICING}

Translating this body of research into police practice is not straightforward, however. With the voluminous research on procedural justice and legitimacy as a point of departure, Stephen Schulhofer et al. (2011) describe a procedural justice model of policing (also see Tyler 2004; Meares 2009). They make the important point that outcomes-say, whether or not the citizen is ticketed, 
searched, or even arrested-are not determinative of citizens' subjective experience; people can be satisfied with their encounter with police even when the outcomes are unfavorable for them, so long as they believe that they were treated justly. The implication is, as they emphasize, that police need not choose between "toughness" and "fairness." Police can be both "tough" and fair when they take enforcement action with cognizance of procedural justice: "Instead of seeking to instill fear or project power, officers would aim to treat citizens courteously, briefly explain the reason for a stop, and, absent exigent circumstances, give the citizen an opportunity to explain himself before significant decisions are made" (Schulhofer et al. 2011, 352). Thus the procedural justice model does not prescribe nonenforcement. It is about how, not whether, police authority is exercised. The procedural justice model is long on the forms that procedurally just policing takes at the street level, and its rationale, but rather short on the managerial measures that police departments should take in order to implement the model. One such measure is to establish procedures for procedurally just policing. Schulhofer et al. suggest that

In connection with street stops, operational guidelines within each department could formalize appropriate steps, such as the need for courteous treatment, the obligation to give the citizen a reason for the stop, and a chance to explain the circumstances. . . . Such steps could be made a routine part of every officer's behavior on the beat. . . officers could easily carry and give to those they stop a card containing a short statement of the rules that govern police stops. The card would enumerate the rights that must be respected (including the right to have the reasons for the stop explained and the right to tell their side of the story before decisions are made) and the procedures for complaining about unfair treatment. (Schulhofer et al. 2011, 354)

We might suppose further that police departments that adopted such a model would establish and enforce expectations that their officers exercise their authority with procedural justice. Their chief executives would make procedural justice an explicit priority, and their expectations would be embodied in departmental policies and procedures. They would train their officers in proper police-citizen interaction (see, e.g., Schuck and Rosenbaum 2011; Skogan, Van Craen, and Hennessy 2014). They would monitor the available indicators of police performance, such as complaints and use of force, and recognizing the limits of these indicators, they would make supervisors responsible for spot-checking the quality of policecitizen encounters. They might even develop more systematic measures of such performance, conducting periodic surveys of citizens with whom their officers have had contact. And they would treat officers with the same procedural justice that they demand of officers in their encounters with citizens, thereby nurturing officers' trust in the organization and their sense of obligation to obey its rules. 


\section{Procedural Justice and Management Accountability}

In most if not all large police departments, the organizational infrastructure is not conducive to the procedural justice model. Even in an era that stresses managerial accountability, the procedural justice with which officers act is typically not measured in police agencies, nor is it an outcome for which police managers are held accountable.

The New York City Police Department's “Compstat” management accountability mechanism has been widely emulated. One of its primary virtues, we believe, is its potential to fix police attention not only on the means-arrests, tickets, and so forth-but on the ends of policing: crime reduction, disorder control, the enhancement of quality of life, and community satisfaction. Accountability mechanisms should stress outcomes, and not simple counts of outputs. If unit commanders are to be held accountable for outcomes, and for mounting good-faith efforts to affect those outcomes in desirable ways, then outputs are important mainly as the manifestations or by-products of effective tactics.

A drawback of Compstat is that the measurement of outcomes is normally confined to crime, and it thus omits important outcomes that ought to be the objects of police attention. Mark Moore describes a range of outcomes, or performance dimensions, that reflect the value of policing, including:

- Reduce criminal victimization;

- Call offenders to account;

- Reduce fear and enhance personal security;

- Guarantee safety in public spaces;

- Use financial resources fairly, efficiently, and effectively;

- Use force and authority fairly, efficiently, and effectively;

- Satisfy customer demands and achieve legitimacy with those policed. (Moore 2002, 131-33)

With reference to case studies of six police departments that were, in the 1990s, implementing community policing, Moore found that only one department accorded high overall importance to performance measurement. More to the object of our concern here, Moore found that three of the six agencies used citizen complaints as a measure of performance with respect to the use of authority, and two used repeated citizen surveys to measure citizen satisfaction. The agencies that tapped these sources of information for performance measures were among the agencies originally selected for study because they "were judged to be making unusually rapid progress toward community policing" (Moore 2002, 159), so they are hardly representative.

We should add that the general community surveys that are administered on an annual or biannual basis by some departments are of limited utility for 
management accountability. Measures of performance that are derived no more often than once every year (or two) are unlikely to either guide police managers or form the basis for holding them individually accountable (Behn 2008). And general, communitywide perceptions of police performance-for example, whether police are in general polite or fair-may not reflect officers' actual performance in police-citizen encounters. We should also add that the procedural propriety of police actions is not measured validly with citizen complaints, which are rarely filed even when citizens are dissatisfied with police service, and which are not infrequently based on misunderstandings of police procedure or on (intentional or unintentional) misrepresentations of police action.

For the purposes of the research summarized here, we therefore undertook to measure citizens' subjective experience, and especially their perceptions of procedural justice, through surveys of people who had recently interacted with police. In each of the two study departments, in Schenectady and Syracuse, New York, semi-monthly samples were drawn from police records from mid-July 2011 through mid-January 2013. Respondents were interviewed by phone within one to five weeks of their contact with police. Following the accumulation of survey data to form a baseline, survey results on citizens' satisfaction and judgments about procedural justice in the contact were summarized and reported to command staffs on a monthly basis through the departments' respective Compstat meetings. Across the eighteen months of surveying, we completed 3,603 interviews, or approximately 100 per month in each city. In this way the project provided for measures of police performance with respect to procedural justice with sufficient periodicity that the information was potentially useful in managing performance. We also interviewed "key informants" in each city, that is, community leaders attentive to police services and knowledgeable about community attitudes, as a potentially larger and more representative slice of public opinion about the police.

Theories of organization form two divergent sets of expectations for how police managers would use the new measures of performance. The management guru Peter Drucker is reputed to have said that "what gets measured gets managed." Thus we might suppose that with monthly feedback about officers' performance in procedural justice terms, managers would pay more attention to how, and not merely whether, their subordinates used their authority and interacted with citizens. As managers-platoon commanders-pay more attention to these dimensions of police work, we might suppose that field supervisors would likewise pay more attention to it. They might remind patrol officers at roll calls about the virtues of procedural justice: its effects on citizen compliance with police, citizen cooperation with law enforcement, compliance with the law, and the public image of the department-its stock of legitimacy. The department might mount in-service training on the rationale for procedural justice and the actions that comprise it. 
It was not our place as researchers to tell managers how to manage; as we told them at the outset, we were there to learn from them.

The second set of expectations for how police managers would manage procedural justice is derived from an institutional perspective on organizations, which we describe in greater depth in chapter 2. From this perspective, we might expect to see the management of what is measured only in a market-driven organization whose productive operations apply a well-known technology with well-established connections to productive output, and we would instead expect to see little such effective management in an institutionalized organization, whose technical "core" is only loosely coupled with many organizational structures. In many respects, as we will explain, police departments resemble institutionalized organizations.

We met with the command staffs of the departments each month to report on survey results, and those meetings also afforded us an opportunity to hear from police managers about their efforts to manage performance. In addition, we interviewed patrol officers and field supervisors at two points in time, about halfway through the eighteen-month survey of citizens, and after the conclusion of surveying, in order to learn more about what, from their perspective, the department was doing to manage this dimension of their performance, and also to learn their reactions to this emphasis on the quality of police-citizen interactions.

Finally, because the Schenectady Police Department had for a number of years provided for audio and video recordings of its officers' activities, we drew a sample of encounters about which citizens had been surveyed and conducted structured observation to independently code features of those police-citizen interactions. For this purpose we formulated an observation protocol that built on the platform of more than forty years of systematic social observation of police in the field. Because we were able to link survey data on citizens' subjective experience to trained observers' independent coding of the behavior of officers and citizens toward one another, encounter by encounter, we can for the first time analyze citizens' subjective experience in terms of independent measures of police behavior. With the observational data we formed a measure of officers' procedural justice and a separate measure of officers' procedural injustice. Thus we can better assess the value of citizen surveys for measuring (and managing) the overt procedural justice with which officers treat citizens.

\section{COMING ATTRACTIONS}

Readers need not wait to learn what we found in this research, inasmuch as we briefly summarize it here. We found that what gets measured does not always get successfully managed. With the introduction of monthly measures of the quality of citizens' subjective experience in their contacts with police reported through Compstat meetings, we detected no substantively significant changes overall in 
either city. Police performance in these terms was fairly high at the outset in both cities, leaving only a little room for improvement. We nevertheless found that efforts to manage the measured outcomes took various forms in each police department, which we arrayed on a management continuum. Among patrol officers and field supervisors, we found a mixed reception to the administrative push for better "customer service": some officers were quite receptive; some exhibited a tempered receptivity; others were quite skeptical.

We can make sense of these findings about management and performance by applying an institutional perspective. Management accountability is only "loosely coupled" to management and to street-level practices. The officers in whose behavior implementation of the procedural justice model rests are not all equally receptive to making customer service a priority, and the implementation of any administrative mandate is mediated by officers' interpretations of its meaning. Officers must make sense of administrative demands, and they vary in the sense that they make of it.

But the story does not end there. In our analysis of police-citizen encounters for which observations were conducted, we found that citizens' subjective experience is very weakly related to officers' procedural justice and only moderately related to officers' procedural injustice. Whether officers used their authority-by using physical force or conducting searches-proved to be much more important than how officers used their authority - their procedural (in)justice-in shaping citizens' assessments of procedural justice. To a significant extent, it appears that the weak relationship stems from citizens' overestimation of police procedural justice: citizen ratings of procedural justice were fairly high even when observed procedural justice was fairly low. These findings challenge the supposition that legitimacy is "created" through police-citizen interactions, and also call into question the extent to which survey data on citizens' perceptions reflect officers' performance. Nor did we find change overall in observed procedural justice by officers in Schenectady, which was moderately high in the first place, and no change in procedural injustice, which was uniformly low. However, in one platoon, whose commander and firstline supervisors were among the more supportive of a customer-service orientation, we detected a modest increase in officers' procedural justice.

These findings raise doubts about the efficacy of the procedural justice model as an approach to police reform. Although it is based on voluminous research concerning public perceptions of police, it is based on assumptions about the strength of the connections: between those perceptions and police actions in police-citizen contacts, and between the adoption of a process-based model of policing and officers' practices on the street.

With that as an overview, we proceed to detail our empirical study. In chapter 3 we summarize what we know about public trust and confidence in police and the forces that influence trust, and present survey-based measures of public trust 
in the two cities. Chapter 4 presents a detailed quantitative analysis of citizens' subjective experiences, while chapter 5 summarizes the sources of citizen dissatisfaction in survey respondents' own words. Chapter 6 presents the findings about officers' behaviors, and especially those that comprise procedural justice, as well as procedural injustice. In chapter 7 readers will find an analysis of citizens' subjective experience in terms of officers' behavior. Chapter 8 summarizes the measurement of procedural justice performance and its incorporation into Compstat, the forms that the management of customer service took, evidence on the effects of management. Chapter 9 describes the varied interpretations of "customer service" that officers applied, and how they made sense of the administrative emphasis on the quality of their treatment of citizens. Chapter 10 summarizes what we found, overall, and discusses the implications of our findings for understanding police legitimacy and procedural justice, for police departments' efforts to build legitimacy, and for future research. We believe that our findings about management, management accountability, and procedural justice can be understood by considering them from an institutional perspective, to which we turn next in chapter 2. 